Article

\title{
The Negotiation of Space and Rights: Suburban Planning with Diversity
}

\author{
Zhixi Cecilia Zhuang \\ School of Urban and Regional Planning, Ryerson University, Toronto, M5B 2K3, Canada; E-Mail: zczhuang@ryerson.ca
}

Submitted: 31 October 2020 | Accepted: 22 February 2021 | Published: 27 April 2021

\begin{abstract}
The increasing suburbanization of immigrant settlement in Canada's major receiving cities has created unprecedented challenges for municipalities. Despite emerging research about the rise of ethnic suburbs in Canada and abroad, the role of suburban municipalities in facilitating immigrant integration and planning with diversity remains unclear. Based on mixed-method ethnographic research, this article investigates how immigrant and racialized communities in the Greater Toronto Area have significantly transformed suburban places and built institutionally complete communities. However, the rapid development of these spaces has not been fully recognized or supported by municipal planning authorities. Conflicts related to land use, public engagement, and public realm development expose planning's failure to keep pace with the diverse needs of immigrant communities, who must continually negotiate and fight for their use of space. Furthermore, the lack of effective civic engagement not only ignores immigrant and racialized communities as important stakeholders in suburban redevelopment, but also threatens to destroy the social infrastructure built by these communities and their 'informal' practices that are often not recognized by the planning 'norm.' Without appropriate community consultation, planning processes can further sideline marginalized groups. Lack of consultation also tends to prevent cooperation between groups, impeding the building of inclusive communities. It is imperative for municipalities to better understand and encourage community engagement and placemaking in ethnic suburbs. This study offers several recommendations for suburban planning with diversity.
\end{abstract}

\section{Keywords}

Canada; diversity; ethnic suburbs; immigrant settlement; institutional completeness; social infrastructure; social space; Toronto

\section{Issue}

This article is part of the issue "Migration-Led Institutional Change in Urban Development and Planning" edited by Robert Barbarino (TU Dortmund University, Germany), Charlotte Räuchle (Free University Berlin, Germany) and Wolfgang Scholz (TU Dortmund University, Germany).

(C) 2021 by the author; licensee Cogitatio (Lisbon, Portugal). This article is licensed under a Creative Commons Attribution 4.0 International License (CC BY).

\section{Introduction}

Across North America, immigrants are increasingly bypassing the inner city and settling directly in the suburbs. In the US, the majority of immigrants (61\%) live in suburbs (Singer, Suro, \& Wilson, 2011) and the Toronto region where this research is situated, $50.6 \%$ of immigrants have settled in peripheral municipalities (Vézina \& Houle, 2017). Traditionally, immigrants were drawn to North America's inner cities as seen in the locations of many typical Chinatowns and Little Italies (Gardaphe, 2003; Lai, 1988). However, the inner city is no longer the first choice for contemporary immigrants, who tend to settle directly in suburban areas for jobs, schools, safety, housing affordability, and wider community networks (Wilson \& Svajlenka, 2014). Other important factors such as exclusion from inner-city socioeconomic fabrics (Tzaninis, 2020) and gentrification-induced displacement have further pushed immigrants out of city centres (Hulchanski, 2010; Keil, 2017).

Immigrant suburban settlements often manifest in noticeable ethnic landscapes that feature not only onestop shopping destinations offering cultural goods and food, entertainment, and personal and business services, but also ethnic institutions (e.g., places of worship, schools, community centres) acting as community 
hubs. Despite this now-established settlement trajectory and emerging research about the rise of immigrant suburbs in Canada and abroad (Dean, Regier, Patel, Wilson, \& Ghassemi, 2018; Farrell, 2016; Gao-Miles, 2017; Harrison, Moyo, \& Yang, 2012; Keil, 2017; Li, 1998, 2009; Lo, Preston, Basu, Anisef, \& Wang, 2015; Lung-Amam, 2015; Qadeer, Agrawal, \& Lovell, 2010; Tzaninis, 2020; Wang \& Zhong, 2013; Watson \& Saha, 2013; Zhuang, 2015, 2019, 2020; Zhuang \& Chen, 2017), how ethnic communities influence and negotiate space, (re)define place, and (re)shape community in Canadian suburbs remains unclear. In addition, the role of municipalities in engaging in multiculturalism and managing ethnocultural diversity is relatively unexplored (Fincher, Iveson, Leitner, \& Preston, 2014). As a result, the growing diversity of the suburbs presents an important opportunity for both planning researchers and practitioners to prioritize the peripheral (Keil, 2017), interrogate the interplay between suburbanization and immigration (Farrell, 2016), and combat perpetuating racial and spatial injustices (Goetz, Williams, \& Damiano, 2020). As ethnic suburbs become more established and numerous, it has become imperative for suburban municipalities to clarify how ethnic communities have shaped and reshaped these places, and more importantly, what municipal planning interventions (e.g., planning policies and processes) are appropriate and effective to manage unprecedented social, cultural, economic, physical, and political changes that challenge conventional suburban planning.

Conventional suburbs are typically characterized by 'desolate placelessness' (Friedmann, 2010). They are often anonymous and lack spatial distinctiveness. Ethnic communities as important stakeholders have much to offer their suburban neighbourhoods, by bringing diverse social, cultural, and economic practices to the space and reinventing a sense of place and community. Suburban municipalities should better recognize and use the contributions of ethnic communities to combat the far-reaching social and economic consequences of lack of distinctiveness (Gleye, 2015; Johnson, 2017; Zhuang \& Chen, 2017).

Previous empirical studies have reported how ethnic communities have significantly transformed existing suburban neighbourhoods and resulted in municipal conflicts related to land use, built form, traffic and parking control, economic development, place-making, and community engagement (Fincher et al., 2014; Harwood, 2005; Linovski, 2012; Lung-Amam, 2015; Poppe \& Young, 2015; Zhuang, 2019; Zhuang \& Chen, 2017). Obstacles facing municipalities may include but not limited to the following: lack of cultural competence, systemic inequality, ineffective community outreach, lack of social infrastructure policy, and imbalanced social and economic priorities. These issues demonstrate municipalities' varying degrees of uncertainty and unpreparedness in addressing ethnocultural diversity and differences, resulting in reactive and ad-hoc planning responses.
Other municipalities have intentionally promoted ethnic suburbs as symbols of multiculturalism and used them strategically in their city branding strategies (Dwyer, Tse, \& Ley, 2016; Pottie-Sherman \& Hiebert, 2015; Schmiz \& Kitzmann, 2017). Such approaches have been critiqued on the basis of cultural commodification and top-down approaches to 'selling ethnicity.' These empirical findings from different jurisdictions point to the need for more comprehensive empirical research on the immigrant suburb phenomenon and its implications for suburban planning with diversity as "positioning planners so that they are more effective, creative and visible in their engagement with ethnic and racialized difference in the contemporary neoliberal city should be a priority" (Fincher et al., 2014, p. 1).

With half of its population born outside of Canada and speaking more than 140 languages, Toronto is well known as one of the most multicultural cities in the world. The increasing suburbanization of immigrant settlement in the Greater Toronto Area offers an excellent opportunity to explore the aforementioned issues. The emerging suburban Chinese and South Asian neighbourhoods are the most visible examples of ethnic concentrations in the Greater Toronto Area and the subject of this research. The terms 'Chinese' and 'South Asian' used in this article are umbrella terms that refer to people whose ancestry originates in China or the Indian subcontinent countries respectively, and whose birthplaces are not limited to other parts of the world including the West Indies, Africa, Asia, and Europe. Despite both terms representing a large spectrum of heterogenous intra-group differences along cultural, religious, linguistic, and geographic lines, the Canadian Census classifies Chinese and South Asians as 2 of the 10 visible minority groups.

South Asians have much shorter mass immigration history in Canada than Chinese immigrants who were among the early settlers in the 1800 s, but have grown very fast as the largest visible minority group in the Greater Toronto Area and in Canada (one and two million respectively) followed by the Chinese group $(0,7$ and 1,6 million respectively; Statistics Canada, 2019). These two very diverse communities have concentrated in Toronto's inner and outer suburbs including Scarborough, Etobicoke, Markham, Richmond Hill, Brampton, and Mississauga. There is not a universally agreed-upon definition of an 'ethnic' place because the ethnic-oriented businesses and institutions are not necessarily limited to immigrant or racialized owners/operators catering to co-ethnic members, and mainstream institutions (e.g., groceries, banks, car dealers) can also target an ethnic clientele by hiring staff from the same group and delivering cultural goods and services. Therefore, the suburban 'ethnic' places presented in this article refer to businesses and institutions clustering in close proximity to Chinese and South Asian residential settlements, and "represent certain ethno-cultural characteristics in 1) the goods and services offered and/or 2) the physical 
features of their storefronts or streetscapes" (Zhuang, Hernandez, \& Wang, 2015, p. 223).

This research involved a mixed-method approach to explore eight Chinese and South Asian neighbourhoods in six suburban regions of the Greater Toronto Area (Mississauga, Brampton, Etobicoke, Richmond Hill, Markham, Scarborough; see Figure 1) based on two research questions:

RQ1: How have immigrant communities shaped and reshaped suburban neighbourhoods?

RQ2: What is the role of municipal planning in managing diversity and facilitating inclusive communitybuilding in these neighbourhoods?

The following sections will first introduce the research context in relation to Canada's suburbanization and the methodological approaches adopted in this research. Next, it will use the case studies in the Greater Toronto Area to illustrate how ethnic suburbs have been constructed through spatial concentration and the development of ethnic-oriented social infrastructure that supports institutional completeness. It will further analyze the tensions between ethnic communities and municipalities in the negotiation for space and rights, and the incompatibility of municipal planning policies and engagement processes. The article concludes with several recommendations for suburban planning with diversity.

\section{Research Context}

The concept of ethnic suburbs, or 'ethnoburbs,' is not new. Li (2009, p. 29) coined the term 'ethnoburb' to describe "suburban ethnic clusters of residential and business districts within large metropolitan areas. They are multiracial/multiethnic, multicultural, multilingual, and often multinational communities in which one ethnic group has significant concentration, but does not necessarily comprise the majority." In her study of the
Chinese community in Los Angeles, the ethnoburb provides ethnic communities with opportunities to build upon an ethnic economy and transform the space into a global economic outpost (Li, 2009). Moving beyond the Chicago School notion of enclaves in central cities (Logan, Zhang, \& Alba, 2002), Qadeer et al. (2010) studied the evolution of suburban ethnic enclaves in the Greater Toronto Area. Here, an 'enclave' refers to both spatial concentration as the necessary condition and "the formation of ethnic businesses, services, institutions and associations" as the sufficient condition (p. 317). In other words, Breton's (1964) concept of 'institutional completeness' referring to the number, size, and variety of institutions that an ethnic community has developed, in fact, is fundamental to make an enclave. These institutions may include formal "organizations of various sorts: religious, educational, political, recreational, national, and even professional" (Breton, 1964, p. 194), which provide strong social ties within the ethnic community, and in turn, create pull factors to attract ethnic group members and sustain ethnic enclaves (Nicholls \& Uitermark, 2016; Qadeer et al., 2010). It also raises questions about to what extent ethnic enclaves affect the social integration process of immigrants (Vézina \& Houle, 2017). However, the notions of 'enclave' and 'ethnoburb' are being challenged by Gao-Miles (2017, p. 99) in her study of an Australian suburb where the spatial formation of ethnicity was conceptualized as interethnic and trans-spatial. She criticized the ambiguity about the degree of spatial concentration, the ignorance of the multiethnic features of these suburban spaces, and "unproblematized binary relations between the white majority and the ethnic other." Considering the analytical perplexity, this article will use 'ethnic/immigrant suburbs' instead to refer to the broadly defined suburban ethnic concentrations.

In addition to the concerns about "problematizing visible minorities through ethnicization" (Gao-Miles, 2017 , p. 84), the emerging ethnic suburbs have challenged the spatial assimilation model and raised questions about increasing segregation and underlying social
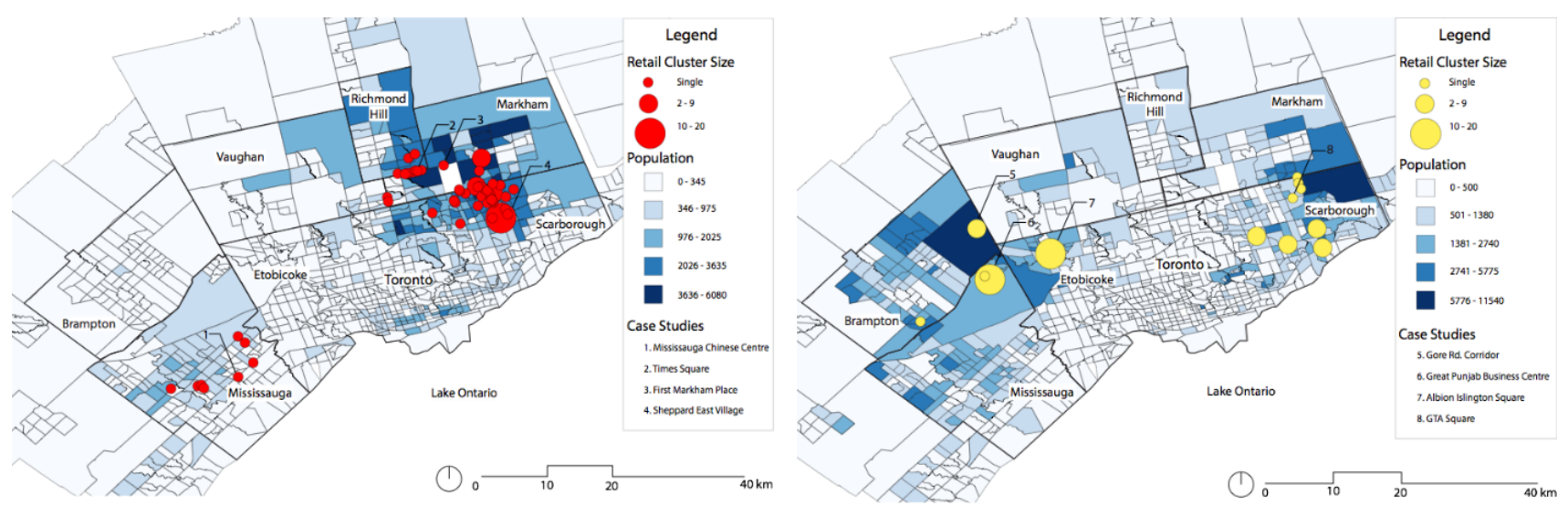

Figure 1. Locations of the eight case studies in relation to Chinese (left) and South Asian (right) populations and retail clusters in the Toronto Census Metropolitan Area. 
and spatial inequality within the suburbs (Farrell, 2016; Fincher et al., 2014; Keil, 2017). Logan's (2014) study of metropolitan America revealed the separate and unequal nature of suburbia where the increasing suburban diversity "does not mean that neighborhoods within suburbia are diverse" (p. 4), suggesting a high degree of segregation similar to the trend observed in central cities.

"In contrast to a story of decline, decay, exception and violence that has been taking shape in the diverse working-class suburbs of the United States," Keil (2017, p. 68) argued that Canada's suburbanization trajectory is different from the American one, and "embedded in an alternative narrative of Canadian immigration and suburbanization." To better understand Canadian suburbia, he further argued: "We had better start in the urban periphery where we find Brampton, Mississauga, or Markham, all suburban municipalities with majority 'visible minority' populations" (Keil, 2017, p. 68). The 'hyper-diversity' represented in these majority minority places refers to an intense diversification of the population in socioeconomic, demographic, and ethnic terms, as well as with respect to lifestyles, attitudes, and activities (Tasan-Kok \& Ozogul, 2017). Although multiculturalism and diversity are largely embedded in Canada's national identity, the diversity discourse runs the risk of being used as a 'glamorized' blanket statement to describe differences in communities without addressing systemic issues of inequity, and a mismatch "between the macro-scale perception of diversity in Canada and the local implementation of national policy" (Tasan-Kok \& Ozogul, 2017, p. 115). The growing diversity challenges suburban governance, policy, and spatial organization that conventionally lacks the supportive social, spatial, and physical infrastructure to build social cohesion among diverse community members as evidenced in Toronto's inner suburbs that are characterized by poverty, ageing high-rise rental apartments, racial and spatial segregation, and insufficient public services (Charmes \& Keil, 2015; Keil, 2017; Pitter, 2016; Poppe \& Young, 2015; Tasan-Kok \& Ozogul, 2017). There is a need to expand the understanding of diversity and use it to interrogate its connection with equity and social justice. Common suburban planning issues related to the growing ethno-cultural diversity are also reflected in the following examples in Toronto's suburbs: 1) immigrants and racialized people being excluded from planning decisions; 2 ) lacking social infrastructure that is ethnic-oriented; 3 ) tensions with segregated and incompatible land uses; 4) using space in ways that attract municipal opposition; and 5) expressing cultural identity within a planning context that does not always consider cultural values (Dean et al., 2018; Hackworth \& Stein, 2012; Lo et al., 2015; Poppe \& Young, 2015; Tasan-Kok \& Ozogul, 2017; Walton-Roberts, 2011; Zhuang, 2019).

Bottom-up grassroots initiative and community activism is one way to tackle the lack of social and physical infrastructure in suburban spaces, as illustrated in Toronto's Jane and Finch neighbourhood where racial- ized residents and community organizations used leftover suburban spaces (e.g., basements, warehouses, unprepossessing malls) to build social infrastructure that supports social ties and community bonding (Tasan-Kok \& Ozogul, 2017). As Klinenberg (2018, p. 5) advocated, social infrastructure as "the physical places and organizations that shape the way people interact" is critical in fighting inequality. However, the community-based fights for space and rights are still insufficient to solve the fundamental planning problems over the long term, partly due to the rigid planning system that generally lacks cultural sensitivity to accommodate diverse needs from underrepresented communities. More importantly, the White supremacy inherent in the planning profession and practices has been an act of racial exclusion, ranging from redlining, exclusionary zoning, White codes, to systemic racial discriminations on housing and public transit (Goetz et al., 2020). These gaps are exacerbated by the settler-colonial planning paradigm and the rise of antiimmigration sentiments, which have renewed conflict over who owns and belongs to/in local spaces including multicultural suburbs (Viswanathan, 2009).

In her seminal work advocating for equity, diversity and inclusive planning, Sandercock (2003, p. 4) argued that, "contemporary cities are sites of struggle over space, which are really two kinds of struggle: one a struggle of life space against economic space, the other a struggle over belonging. Who belongs where?" The manifestations of multicultural suburbs have several implications for the work of planners including changing physical form (whether 'exotic' design fits in with the neighbourhood's character), demographic change and social inclusion (who belongs to and in the neighbourhood) and competing claims for community authorship (who gets to tell the story of the neighbourhood). Fincher et al. (2014) argued that as a lived reality, multiculturalism requires local planning to engage with ethnocultural differences and support social inclusion beyond the common focuses on settlement services and/or economic benefits. The theories of planning for and with multicultural diversity, such as communicative/collaborative planning emphasize the planner's role in mediating among stakeholders involved in the planning situation (Fainstein, 2000). Traditional engagement methods fail to effectively reach and incorporate the lived experiences of marginalized and immigrant groups and the transformative power of their local knowledge. Without appropriate community consultation, planning processes often marginalize already minoritized groups. This lack of consultation also tends to prevent cooperation between groups, thus impeding the building of inclusive communities.

Researchers have also argued that a truly comprehensive engagement process should create opportunities for dialogue that engage a full cohort of community members (Thomas, Pate, \& Ranson, 2015; Toolis, 2017; Zhuang \& Chen, 2017) and consider any ingrained power imbalances (Eckenwiler, 2016; Nejad \& Walker, 
2018). City planners can play an important role in creating opportunities for dialogue around place and ensuring that all community members are included. It is thus important for them to consider the specific context of each city where immigrants settle. Rios and Watkins (2015) called planners 'cultural brokers,' meaning that they can function as intermediaries to navigate and negotiate between policies, practices, and the diverse groups with different needs and different perspectives on place. The goal is not to come to a weak consensus or compromise between different cultural communities, but rather to create new spaces where recognition, respect, and trust can be encouraged (Rios \& Watkins, 2015).

Municipalities, and especially city planners who are at the forefront of urban development, need to develop a clear understanding of the processes and mechanisms involved in the making of ethnic suburbs, where conventional planning practices (e.g., homogeneity and segregation in land use and by socioeconomic status) is often at odds with an increasing public commitment to equity, diversity, and inclusion. By focusing on Chinese and South Asian communities in Toronto's suburbs, this study will help clarify how ethnic neighbourhoods are shaped in a range of suburban contexts, and how municipalities could 'manage' diversity and plan inclusive communities.

\section{Research Approach}

The research started with the identification of Chinese and South Asian residential and business concentrations in the six studied suburban areas. The data were collected through mapping Chinese and South Asian residential concentrations based on the 2016 Canadian Census and extensive site visits to 112 Chinese and South Asian retail clusters of more than 3800 businesses that are in close proximity to the residential population of the respective communities. Eight case study neighbourhoods were then selected for more in-depth investigations (Figure 1).

Semi-structured interviews and three focus groups were conducted with 77 key informants, including immigrant entrepreneurs, city planners, an architect, developers, business improvement area managers, and religious and community leaders. The interviewed merchants and other community members were recruited through doorto-door visits and snowball referrals. These individuals either live, work, and/or operate their business in the studied neighbourhood. As a result, their lived experiences and engagement in the area provided important insight into the interview questions, such as business location preferences, perspectives on neighbourhood change and community development, the construction of cultural identity, barriers to engagement, and working relationship with municipal officials. The professionals (planners, developers, and one architect) were recruited based on their active involvement in local development matters. They provided professional opinions about the role of planning policies and public engagement pro- cesses in shaping the neighbourhoods and building inclusive communities. In addition, intercept surveys were conducted with 81 visitors at each case study site (minimum 10 each). They were asked about their users' experiences when shopping, socializing, and seeking community services in the area, and their views on the neighbourhood's characteristics and cultural identity.

At least five visits to each case study site were conducted to gain first-hand observations and collect business baseline data (e.g., business composition, ethnic contents, vacancy, etc.). Archival research was used to provide historical and demographic information of the areas. Finally, a thorough policy review was carried out to provide the regulatory contexts. Policies, bylaws, and related plans, guidelines, and studies were reviewed from one single-tier municipality (Toronto), two uppertier municipalities (York and Peel Regions), and four lower-tier municipalities (the Town of Richmond Hill and the Cities of Markham, Mississauga, and Brampton). Richmond Hill and Markham are under the governance of York Region, and Mississauga and Brampton are under the governance of Peel Region. The municipal documents and field observational data helped contextualize local developments in each study site, while the census and business data helped compile neighbourhood socioeconomic profiles.

The following sections present the dynamic nature of the case study neighbourhoods followed by the discussions about negotiating space and rights and the planning responses reflected in policies and public engagement processes.

\section{Building Institutionally Complete Communities}

According to Breton (1964), institutional completeness can be measured using two indicators: the density and diversity of local institutions. Using this measurement, the case study sites have relatively high degrees of institutional completeness, satisfying the needs of co-ethnic community members as well as the community at large. These sites generally are situated in areas with more ethno-cultural diversity than the city average based on various demographic indicators such as ethnic origin, visible minority, recent immigrant and foreign-born population, religion, mother tongue, and home language. These are the typical majority minority neighbourhoods with hyper-diversity as suggested in the literature. Table 1 highlights the visible minority and foreign-born populations in the study areas. The growth of immigrant populations drives the demands for both ethnic and mainstream retail, and the concentration of ethnic businesses served as the catalyst for nearby residential developments attracting the co-ethnic community, because they offer a large variety of cultural goods and personal and professional services that specifically cater to the diverse cultural needs of the ethnic communities. For example, both Chinese and South Asian clusters heavily feature service-oriented businesses, such 
Table 1. Ethno-cultural profiles of the eight case study neighbourhoods.

\begin{tabular}{|c|c|c|c|}
\hline & Population & Visible Minority & Foreign-born Population \\
\hline Toronto & $2,503,000$ & $\begin{array}{l}46.4 \% \\
\text { South Asian: } 11.9 \% \\
\text { Chinese: } 11.3 \% \\
\text { Black: } 8.3 \%\end{array}$ & $49.4 \%$ \\
\hline \#7 Albion Islington Square & 9,928 & $\begin{array}{l}52.9 \% \\
\text { South Asian: } 46.3 \% \\
\text { Black: } 27.6 \% \\
\text { Latin American: } 9 \%\end{array}$ & $54.9 \%$ \\
\hline \#4 Sheppard East Village & 34,964 & $\begin{array}{l}81.5 \% \\
\text { Chinese: } 63.3 \% \\
\text { South Asian: } 17.6 \% \\
\text { Black: } 6.1 \%\end{array}$ & $69.5 \%$ \\
\hline \#8 GTA Square & 17,881 & $\begin{array}{l}90.4 \% \\
\text { Chinese: } 54.8 \% \\
\text { South Asian: } 25.1 \% \\
\text { Filipino: } 6.7 \%\end{array}$ & $70.5 \%$ \\
\hline Brampton & 433,806 & $\begin{array}{l}57.0 \% \\
\text { South Asian: } 55.6 \% \\
\text { Black: } 21.7 \% \\
\text { Filipino: } 4.9 \%\end{array}$ & $47.5 \%$ \\
\hline \#5 Gore Rd. Corridor & 11,648 & $\begin{array}{l}56.7 \% \\
\text { South Asian: } 59.3 \% \\
\text { Black: } 12.1 \% \\
\text { West Asian: } 4.2 \%\end{array}$ & $61 \%$ \\
\hline Mississauga & 668,599 & $\begin{array}{l}48.8 \% \\
\text { South Asian: } 41.3 \% \\
\text { Chinese: } 14.1 \% \\
\text { Black: } 12.3 \%\end{array}$ & $51.3 \%$ \\
\hline \#6 Great Punjab Business Centre & 24,363 & $\begin{array}{l}79.1 \% \\
\text { South Asian: } 63.6 \% \\
\text { Black: } 17.2 \% \\
\text { Southeast Asian: } 4.2 \%\end{array}$ & $64.3 \%$ \\
\hline \#1 Mississauga Chinese Centre & 25,861 & $\begin{array}{l}28.7 \% \\
\text { South Asian: } 26.1 \% \\
\text { Filipino: } 17.3 \% \\
\text { Chinese: } 15.1 \%\end{array}$ & $48.4 \%$ \\
\hline Markham & 261,573 & $\begin{array}{l}65.2 \% \\
\text { Chinese: } 52.4 \% \\
\text { South Asian: } 26.4 \% \\
\text { Black: } 4.7 \%\end{array}$ & $56.5 \%$ \\
\hline \#3 First Markham Place & 12,157 & $\begin{array}{l}79.9 \% \\
\text { Chinese: } 78.7 \% \\
\text { South Asian: } 11.4 \% \\
\text { Black: } 1.9 \%\end{array}$ & $67.2 \%$ \\
\hline Richmond Hill & 162,704 & $\begin{array}{l}45.7 \% \\
\text { Chinese: } 46.8 \% \\
\text { South Asian: } 15.3 \% \\
\text { Black: } 4.7 \%\end{array}$ & $51.5 \%$ \\
\hline \#2 Times Square & 15,716 & $\begin{array}{l}69.3 \% \\
\text { Chinese: } 67.4 \% \\
\text { South Asian: } 12.6 \% \\
\text { West Asian: } 5.7 \%\end{array}$ & $64.4 \%$ \\
\hline
\end{tabular}


as hair and beauty salons, health clinics, and offices for law, immigration, accounting, educational training, real estate, and travel, representing $47.9 \%$ and $52.8 \%$ of the total businesses, respectively. Retail businesses accounted for nearly one-third of the businesses in both Chinese (29.8\%) and South Asian (28\%) neighbourhoods, and the rest were food-related (Chinese: $22.4 \%$; South Asian: $18.8 \%$ ), such as restaurants, grocery stores, bakeries, takeout eateries, banquet halls, etc. Compared with mainstream retail facilities that generally provide balanced shares of services, retail, and food-related businesses, the much higher composition of ethnic-oriented services found in these sites suggest that they are not only the shopping destinations, but also play an important role in facilitating day-to-day social activities and serving a wide range of community needs, needs that may not be fulfilled by mainstream institutions (e.g., language school, Chinese medicine clinic, cultural goods and services). From this perspective, suburban ethnic retail spaces can also be considered important community spaces providing essential community services. They help build the needed social infrastructure that can benefit the community at large.

Retail sites were also well integrated with other ethnic-oriented institutions on site or within proximity, such as places of worship, private schools, and community centres. These ethnic places complement each other in providing needed infrastructure and act as important community anchors. This level of institutional completeness is most prominent in the South Asian Great Punjab Business Centre and Gore Road corridor case studies. The former houses the Sikh Heritage Museum and is strategically located next to a long-established Sikh gurdwara and a Sikh private school. The latter has two Hindu mandirs, a gurdwara, two banquet halls, a recreation centre for seniors and youth, a Sikh private school, and an Islamic service centre onsite, and is located near another long-established Hindu temple and the site of a newly proposed mosque. These ethnic-oriented institutions play important roles in the social and economic vitality of the neighbourhoods, as in addition to visiting the shops, residents and visitors frequent the place for multiple daily prayers and for easy access to community services.

This finding is further confirmed by extensive field observations and 81 intercept surveys with visitors. Many social activities, especially among co-ethnic members, were observed in various types of retail spaces (e.g., storefronts, food courts, parking lots, lobbies and hallways of indoor shopping malls), including seniors practicing tai chi and fan dance, playing chess and walking, parents chatting with each other at children's extracurricular learning centres, youth hanging out in programmable spaces in indoor malls, co-workers socializing during lunch hours, and visitors and community members attending indoor and outdoor cultural events. These retail spaces, in fact, create 'third places,' a term coined by Oldenburg (1999) referring to spaces that pro- mote social interactions and community-building. They are part of the social infrastructure that serves as the building blocks of public life (Klinenberg, 2018). The following intercept survey data provide more details of visitors' experiences in these retail third places: Nearly onethird $(29.6 \%)$ of the visitors who completed the intercept survey indicated that they came to the retail areas for social reasons other than shopping. Many respondents interacted with strangers in the shopping areas (21\%); many others knew some of the business owners or operators personally $(25.9 \%)$. Of the 81 intercept survey respondents, 58 (71.6\%) were members of the respective ethnic community. The vast majority of respondents (95\%) felt at home in the retail area they visited. When asked whether the shopping area reminded them of another place, many referred to similar ethnic retail clusters in the Greater Toronto Area or significant landmarks in China and India, such as the Section 17 in Chandigarh in Punjab, or Times Square in Hong Kong. Nearly half of the respondents $(46.9 \%)$ considered the shopping area to be a public space that people could access without spending any money. One respondent said that in his culture (Tamil): "Males go work; household wives come to [the mall to] hang out after they're done their chores."

Unlike conventional suburban neighbourhoods that are generally homogeneous, segregated, and 'placeless,' the studied Chinese and South Asian neighbourhoods present a high degree of institutional completeness and both communities have significantly transformed the spaces by adding new meanings, new identities, and new community functions. However, the rapid changes that accompany growing concentrations of immigrants can also create tensions as they have not been fully recognized or supported by municipal planning authorities. Conflicts related to land use, public engagement, and public realm development continue to arise, exposing planning's failure to keep pace with the diverse needs of immigrant communities, who must continually negotiate their use of space and fight for their rights to their spaces. The following sections explore the challenges and the role of municipalities in managing diversity and facilitating or impeding ethnic communities' engagement in suburban neighbourhoods.

\section{The Negotiation for Space and Rights}

\subsection{Ethnic Succession and Redevelopment Pressure}

The eight case studies were investigated in more depth to reveal the processes and mechanisms involved in the evolution of suburban ethnic neighbourhoods. With regard to strip malls, two prominent and longestablished retail neighbourhoods reflect how ethnic businesses organically readapted existing shopping strips and transformed the neighbourhoods: Albion Islington Square Business Improvement Area in Etobicoke, which primarily features South Asian businesses; and Sheppard 
East Business Improvement Area in Scarborough, which has a mix of Asian-oriented and mainstream businesses.

Both inner suburb locations experienced rapid suburban developments in the 1950s and 1960s featuring low-density and car-oriented streetscapes, and the strips were initially occupied by European and mainstream businesses as business owners and shoppers recalled. With the influx of South Asian and Chinese immigrants to the respective areas in the 1980s, ethnic businesses started to move in and occupy storefronts along retail strips that were built on major arterial roads and are in close proximity to high-density residential areas with a large number of immigrants. Both areas have grown to include 200 and 500 businesses, respectively, and are currently operated under the City of Toronto's Business Improvement Area program, which is a joint partnership between the city and local business people to maintain and improve physical streetscapes, promote economic development, and enhance community life of the business areas. Both Business Improvement Areas are actively involved in beautifying the streetscapes by putting up lights, flowers, and banners and hosting street festivals. However, compared with the most successful inner-city Business Improvement Areas, which are typified by compact built forms, mixed uses, buildings with historic and architectural value, and pedestrian-friendly streets, the suburban strip malls are the exact opposite: They are disadvantaged by physical and structural barriers to rejuvenation and public gathering. These strip malls could easily be targeted for intensification and redevelopment, as suggested by Linovski (2012), which could translate to increased pressure on the current ethnic businesses which look less desirable from a conventional urban design perspective. These two strip malls illustrate the challenges faced by the majority of ethnic strips in this study: They shared similar re-adaptation processes associated with immigrant settlement patterns but are facing an uncertain future. As one Business Improvement Area manager who grew up in the neighbourhood commented:

A lot of [immigrant] businesses have been here for 20 or 30 years. The social connection [they] have established with the residents or consumers is definitely important and they know the area in and out....This area has been vibrant and viable for so many years that it definitely gets missed. And sometimes people don't know that we have such a concentration of ethnic stores.... I definitely think our area should never be forgotten...[If] these big box stores [were] coming here and replacing these small businesses...destroying everything and then rebuilding to make it look like every other area... we wouldn't be open to it.

These retail 'third places' serve as important social infrastructure in the neighbourhood. Beyond their shabby appearances and poor physical conditions, there was an active social and economic life that should not be ignored or removed in the name of redevelopment or gentrification.

\subsection{Tensions with Incompatible Land Uses}

The other six shopping plaza and indoor mall case studies were mainly created by ethnic developers. Interestingly, four of the six retail sites (Gore Road corridor, Great Punjab Business Centre, Mississauga Chinese Centre, and the Greater Toronto Area Square) are zoned as employment and industrial uses that were not intended for retail commercial. Therefore, a rezoning process is required to add retail uses to these industrial lands. However, municipalities generally endeavour to protect the supply of employment lands and permit non-ancillary retail uses only when they directly serve the primary function of the area. These incompatible land uses easily created tensions between the municipalities and the business communities as reflected in a 10-year controversy in the case of the Great Punjab Business Centre.

The initial retail development proposal targeting the South Asian community was not accepted. In order to gain the planning approval, the developer then modified the proposal, indicating it would be used as industrial units (e.g., warehousing), not commercial, which means each unit cannot exceed $20 \%$ of the floor space for retail use according to the city's zoning bylaw. However, over time, many South Asian business owners have tried to convert the units to $100 \%$ retail use in order to meet the increasing needs of the community and capitalize on the growing ethnic market. One planner recalled: "Some have gone ahead and done that, some have been prosecuted. There have been applications to the Committee of Adjustment to make modifications to those to have $100 \%$ retail and we've resisted that so far." Some business owners appealed to the Ontario Municipal Board (now called the Local Planning Appeal Tribunal), a quasijudicial body that handles appeals of land-use planning disputes, but were turned down because the proposed uses did not comply with the bylaws. Without a clear solution to incompatible or even illegal uses, some local retail stores hid their merchandise (e.g., clothing, fabrics, jewelry) at the back of the store and claimed their business was a warehouse when bylaw enforcement officers arrived.

After 10 years of controversy, the planning policy department is now reconsidering the site and a rezoning process is underway. Specifically, the city has exempted the site from conducting a municipal comprehensive review as part of a rezoning application, as explained by the Planning Manager:

Because we want to preserve as much of the industrial land as possible, until we want to take a look at it comprehensively or holistically across the entire city to see which areas we're comfortable with having that conversion done. And so this area was one 
of the ones that were identified, saying we won't be terribly upset if it converts over to retail. Part of that reason is because I think it's been operating for retail, and you do have a school to the immediate south and [the gurdwara].

This decision sent a welcoming message to the local business owners who purchased individual units from the developer but were generally uninformed about permitted uses within their business. Although it took 10 years for city planners to finally acknowledge the importance of this retail centre to the local community, the decision indicates that municipalities are willing to understand the needs of ethnic communities and be flexible in planning to find a common ground to support the creation of an inclusive community.

\subsection{The Need for Community-Based and Culturally Sensitive Planning and Design Approaches}

Many ethnic establishments in this study feature generic North American suburban architecture with no visible exterior ethnic markers, with the exception of a few case studies where cultural identities are unapologetically expressed through elaborate architectural features and public arts (Figure 2). These features help inscribe these sites with cultural, historical, and political meanings. For example, the elaborate Hindu and Sikh temples on the Gore Road resemble religious architecture in India; the 43-feet tall entrance archway and other replicas of Chinese architectural and gardening features at the Mississauga Chinese Centre symbolize Chinese culture; a statue of the founder of the Sikh Empire at the Great Punjab Business Centre commemorates the community's history; and on the same site, a Komagata Maru monument and a Sikh Heritage Museum remind visitors of how Sikh immigrants fought to claim their space and rights in Canada despite being excluded by the earlier discriminatory immigration policies. It is clear that ethnic communities are securing a sense of belonging and identity through their placemaking practices.

The actual place-makers who initiated these cultural, commercial, and religious places were in fact, the ethnic developers, who led the negotiation with planning authorities and hoped to make an influence by addressing community needs and achieving business success. For example, the development of the Hindu Sabha Temple was a result of displacement from the governmental land expropriation to make way for a toll highway. The temple as the first structure built in the middle of farmlands 30 years ago was the catalyst for the later neighbourhood development along the Gore Road corridor which is now surrounded by residential subdivisions and centres over 400 businesses, places of worship, and community facilities serving the South Asian community.

A Sikh retail developer I interviewed was among several ethnic developers who have built retail plazas in the area and has been working closely with the community by listening to their concerns (e.g., the lack of worship and community space in the neighbourhood). As a result, instead of building more retail units, they moved forward with the development of a gurdwara on the retail site and built "the best of its kind in North America" with high building standards, sophisticated vernacular styles, and spaces for community activities. This developer further commented about how short-sighted the city was and how important to engage the community to correct the wrong policy direction and reshape the space:

The City made a big mistake. We know for a fact that the area has been over-zoned for retail. As a result, the area is overdeveloped with retail and some businesses have not survived due to the competition....So, I would say as the developer we have done much to influence the character of the plaza, however, it is also very much the community that contributed to the character....We have received feedback from a lot of folks saying they are very grateful about being able to walk to the plaza [and the gurdwara]. We feel good that we can provide a greater community good for people, aside from just the business and profitability side of it.

Another criticism is about the rigid design guidelines that only reflect the conventional cultural values, as the retail developer further revealed:

The physical features of the [retail] building [we built] do not represent a cultural design....The City said the windows must match the oval windows of the
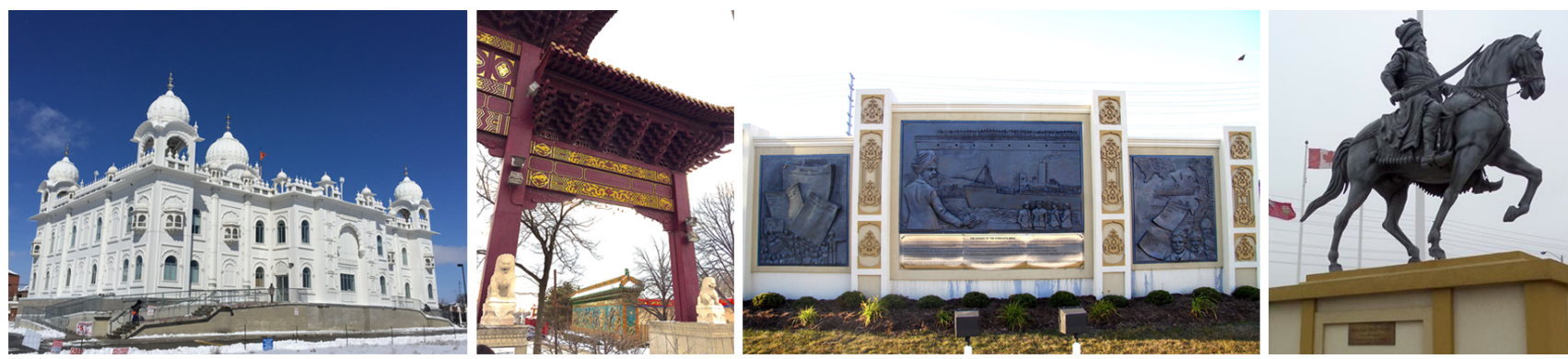

Figure 2. Cultural expressions in architectural features and public arts. Note: From left to right: Sikh Gurdwara; Mississauga Chinese Centre; and Monument and sculpture at the Great Punjab Business Centre. Source: Author. 
approximately 100 -year-old church nearby. We didn't originally want oval windows but had to design it accordingly to be approved.

An architect also echoed the insensitivity and how "indifferent" planners were towards culturally sensitive designs during the Great Punjab Business Centre site plan approval process:

The planning department has too much input on [conventional] design....We were fighting for having more public space than parking spaces [because of the need for community events and pedestrian flow]...[Also], I don't think they had much to say [about the Sikh architectural design]....I wonder if they were either happy completely...or because they never dealt with something like this before that was one of the hurdles on their end.

The architect further emphasized the importance of gaining community input and support through the creation of public art and a Sikh Heritage Museum as defining features of the space. Similar cultural needs were also expressed in the interviews with merchants and community members across the study sites, such as more public spaces for cultural events, artwork with cultural expressions, Asian night markets, and sidewalk sales. These cultural views of space and social infrastructure present new challenges and opportunities to conventional suburban planning and design.

\section{The Planning Responses: Policies and Public Engagement}

The five municipalities in this study present prominent immigrant and racialized populations as shown in Table 1. Various documents identify the impact that these communities have had on the municipalities. For instance, the Town of Richmond Hill's (2020) official plan acknowledges that the presence of immigrants has fueled the demand for ethnic commercial businesses. Similarly, the Regional Municipality of York's (2015) retail trends study concludes that the growth of immigrant populations will drive demand for both ethnic and mainstream retail; the City of Toronto's (2019, pp. 3-39) official plan highlights the economic opportunities and connections brought by immigrants which means "Toronto's economy is 'plugged into' the rest of the world in ways hardly imaginable 30 years ago." However, these acknowledgements only highlight the economic benefits associated with immigration without explicit statements on developing a permissive policy environment to support ethnic communities' place-making efforts and settlement needs. Only the City of Brampton's (2020) Official Plan expressly states that planners ought to be flexible and adaptive to the needs of growing immigrant populations. There is a lack of institutional support in these official planning policies despite many of them listing place-making and human-scale development as one of its development objectives.

Overall, it appears that planning policies accommodate ethnic communities by reacting to their presence, rather than planning proactively for them. For example, the City of Mississauga's (2018) Dundas Connects Master plan considers the Mississauga Chinese Centre area as a unique commercial corridor, which draws regional markets and provides cultural goods and services not commonly found in other places. Similarly, the City of Brampton's (2018) Vision 2040 acknowledges the Gore Road corridor's significance for the South Asian community. The resulting policies support the ongoing commercial activity in the area. However, this policy direction seems to be at odds with what the community needs as discussed in the earlier section.

Since public engagement is required in planning legislation, municipalities generally have high-level vision statements that address inclusive engagement with the public. Some of the more substantial references to immigrant communities appear in economic development and strategic planning documents, such as in Richmond Hill's economic development strategy that labels engagement with immigrant communities as a high priority action and an opportunity to drive business investment. However, conventional public engagement approaches generally lack careful consideration of how to effectively engage immigrant and racialized communities in decision-making (Grewal, 2020). It often results in mistrust between municipalities and the communities, potentially harming their long-term relationship and the city's sustainability.

The interviewees in this study collectively revealed the struggle that ethnic communities face in the absence of municipal support or recognition. Many of these communities remain invisible or insignificant in municipal agenda or major redevelopment initiatives. For example, Sheppard East Village is a popular landing pad for newcomers but is also stigmatized with poverty and crime. The local businesses and residents have been actively working with planners and politicians to fight for relaxed zoning regulations and transit development for a decade; yet their appeal for revitalization still has not been addressed by the City partly due to the lack of a comprehensive retrofitting scheme that can address widening socioeconomic disparities in the area. In the case of the Gore Road corridor, the interviewed senior planner who was working on the Official Plan review surprisingly had no knowledge of this vibrant community hub and had to locate it on Google map. Local community members were not consulted in any major developments around the area until recently, when the City launched its Vision 2040 Strategic Plan. The City invited local businesses and residents to a series of neighbourhood walks to collect community input concerning the future of the corridor. Similar issues were brought up by interviewed merchants who operated their businesses along the major transit corridor that connects Richmond Hill and Markham. 
While new suburban retrofitting schemes were promoted through public transit investment and intensification, these immigrant entrepreneurs who were directly affected were not engaged. It was largely due to the ineffective public engagement approaches (e.g., town halls) that discouraged immigrant entrepreneurs who faced language barriers and had fear of power imbalance to actively participate.

When asked about planners' outreach experiences in ethnic communities, one interviewed community planner working on a major revitalization project near the Great Punjab Business Centre admitted that:

We don't get a lot of questions and asking for help from the South Asian business owners. I think some of them are still trying to understand who we are and how this works....There is a discrepancy in terms of what the businesses want to do for marketing and what [the city] wants them to do.

When asked about the role of planners in supporting immigrant place-making and creating inclusive communities, most of the interviewed planners agreed that municipalities can encourage people to do things for the greater community and can even enable things by granting permission. However, they felt it should be the people who initiate place-making, whether the developers or the communities, rather than the city. One senior planner at the City of Brampton stated:

So really [we are] looking at planning like a tool to kind of support the community. But if it's us [planners] coming in and governing what place-making is or what sense of place is, that's a total failure from my perspective. I don't think that works because we are not from that community so you can't really speak on that behalf.

The lack of active outreach prevents planners from effective communication with ethnic communities and the co-creation of better communities that leverage the strengths of diversity. The Mississauga Strategic Plan observes with a critical lens that:

Widespread cultural diversity hasn't translated into a rich urban environment, in architecture, services, or retail. Mississauga's diversity has the potential to express itself more prominently, to fundamentally change the experience of the city, and leverage our identity as a mature urban centre. (City of Mississauga, 2009, p. 26)

It is also important to clarify the municipal processes (e.g., policy, planning and design, public participation) related to ethnic neighbourhoods, and to identify strategies and processes that support or hinder ethnic place-making.

\section{Discussion and Conclusions}

Toronto's diverse demographics bring the world to the city. However, a diverse population does not necessarily mean inclusive integration. What has remained challenging is how to best understand immigrants' integration processes and experiences in cities and neighbourhoods. Clarifying the effects of global migration on local communities is important for cities to consider municipal governance, policies, infrastructure, and service provisions required to facilitate and support immigrant settlement and integration. As revealed in the case studies, suburban ethnic neighbourhoods have not been seriously considered and integrated into planning processes and outcomes. Many of these communities have a high degree of institutional completeness fuelled by the demands for cultural goods, services, and spaces that facilitate cultural practices, ethnic bonding, and social interactions. The ways they function and organize with mixed uses, social infrastructure, and cultural expressions are considerably different from conventional suburban neighbourhoods that are typified with segregated land uses, homogenous landscapes, and auto-oriented built environment (Gao-Miles, 2017; Lung-Amam, 2015; Zhuang, 2019). More importantly, the developments of ethnicoriented institutions were largely driven by members of the ethnic communities (e.g., developers, entrepreneurs, religious groups), who not only demonstrated strong desires to take part in the (re)investment of suburban spaces, but also demanded more flexible and adaptable municipal policies and regulations to acknowledge and support ethnic places and infrastructure. As demonstrated in this research, suburban municipalities lack a thorough understanding of the cultural needs of ethnic communities and the role of social infrastructure in supporting institutional completeness. Furthermore, the lack of effective civic engagement not only ignores immigrant and racialized communities as important stakeholders in suburban redevelopment, but also threatens to destroy the social infrastructure built by these communities and their 'informal' practices that are often not recognized by the planning 'norm.'

It has become imperative for suburban municipalities to understand the social, economic, cultural, political, and physical constructs of these ethnic neighbourhoods and be more proactive in engaging ethnic communities in the co-creation of inclusive communities. There is an urgency to identify and change the narratives in how municipalities should recognize immigrant communities' perspectives on neighbourhood change and community development, the way they build and use social infrastructure, the construction of cultural identity, and the barriers to engagement. The social infrastructure developed in these institutionally complete communities should be promoted as community assets and be further enhanced through explicit policies and programming. Consultations and negotiations should take place to ensure that inclusive spaces supporting the community's 
diversity can be created. Non-consultative planning processes also threaten to erase the informal place-making practices and outcomes that emerge within immigrant communities as they attempt to meet their own needs from the margins and preserve their cultural identities. An inclusive and equitable public consultation process will not only amplify the voices of minority communities, but also enhance civic engagement for everyone.

In conclusion, this study offers the following recommendations for planning practices. First, consideration of social equity and inclusion should be the municipality's priority and employed in all decision-making. Municipal policies must apply an equity lens to a range of immigrant settlement and integration matters, such as housing, education, employment, entrepreneurship, transportation, community services, and connect these matters to the broader community context, especially in the planning for the public realm, neighbourhood change, heritage preservation, and community resilience. Equitable and inclusive policies will help ensure a level playing field for ethnic communities to fully participate as key players. Their formal and informal place-making and communitybuilding practices should not be ignored or removed from the institutionalized process.

Second, municipalities should revisit municipal policies, engagement processes, programming, and service deliveries to ensure they are culturally sensitive and appropriate for diverse communities.

Third, planners should prioritize community engagement and collaboration to inform decision-making. Public consultation conducted as a minimum statutory requirement may do little to promote community ownership of plans, particularly when working with groups who face a myriad of barriers to engagement, including language, age, gender, or feelings of powerlessness.

Fourth, planners should also avoid tokenistic public consultation approaches. A renewed and empowered community process should be adopted to ensure under-represented groups have their own space to voice their concerns and engage in the co-creation of planning solutions.

Finally, a high degree of institutional completeness should be considered an asset of the suburban neighbourhood. Municipalities should conduct asset mapping of the existing cultural facilities and (re)invest in the established social infrastructure. This asset planning process should also involve considerations of shared spaces, uses, and services with the wider community, which will help transition from co-ethnic bonding to intercultural bridging.

\section{Acknowledgments}

This article draws on research funded by Social Sciences and Humanities Research Council and is supported by a Publication Grant, Faculty of Community Services, Ryerson University. The author would like to acknowledge the help of the participants in this study who gen- erously contributed their time and shared their perspectives. They made this research possible. Special thanks go to Linn Clark, and the anonymous reviewers for their insightful comments. The author is, of course, solely responsible for the content of this article.

\section{Conflict of Interests}

The author declares no conflict of interests.

\section{References}

Breton, R. (1964). Institutional completeness of ethnic communities and the personal relations of immigrants. American Journal of Sociology, 70(2), 193-205.

Charmes, E., \& Keil, R. (2015). The politics of postsuburban densification in Canada and France. International Journal of Urban and Regional Research, 39(3), 581-602.

City of Brampton. (2018). Living the mosaic: Brampton 2040 vision. Brampton: City of Brampton. Retrieved from https://www.brampton.ca/EN/CityHall/Documents/Brampton2040Vision/ brampton2040Vision.pdf

City of Brampton. (2020). Official plan. City of Brampton. Retrieved from https://www.brampton.ca/EN/CityHall/Official-Plan/pages/official-plan-background. aspx

City of Mississauga. (2009). Strategic plan. Mississauga: City of Mississauga. Retrieved from http:// 184.150.237.247/file/COM/StrategicPlan_Web_04_ 22_2009.pdf

City of Mississauga. (2018). Dundas connects master plan. Mississauga: City of Mississauga. Retrieved from https://s3.ca-central-1.amazonaws.com/ehqproduction-canada/documents/attachments/ 4045b61197fdcbe024371bb90b50f2fd1f7ffb0d/ 000/009/328/original/20180319_Dundas_ Connects_Master_Plan_WEB.pdf

City of Toronto. (2019). Toronto official plan. Toronto: City of Toronto. Retrieved from https://www. toronto.ca/wp-content/uploads/2019/06/8f06OfficialPlanAODA_Compiled-3.0.pdf

Dean, J., Regier, K., Patel, A., Wilson, K., \& Ghassemi, E. (2018). Beyond the cosmopolis: Sustaining hyperdiversity in the suburbs of Peel Region, Ontario. Urban Planning, 3(4), 38-49.

Dwyer, C., Tse, J., \& Ley, D. (2016). 'Highway to heaven': The creation of a multicultural, religious landscape in suburban Richmond, British Columbia. Social \& Cultural Geography, 17, 667-693.

Eckenwiler, L. A. (2016). Defining ethical placemaking for place-based interventions. American Journal of Public Health, 106(11), 1944-1946.

Fainstein, S. S. (2000). New directions in planning theory. Urban Affairs Review, 35(4), 451-478.

Farrell, C. R. (2016). Immigrant suburbanisation and the 
shifting geographic structure of metropolitan segregation in the United States. Urban Studies, 53(1), 57-76.

Fincher, R., Iveson, K., Leitner, H., \& Preston, V. (2014). Planning in the multicultural city: Celebrating diversity or reinforcing difference? Progress in Planning, 92, 1-55.

Friedmann, J. (2010). Place and place-making in cities: A global perspective. Planning Theory and Practice, 11, 149-165.

Gao-Miles, L. (2017). Beyond the ethnic enclave: Interethnicity and trans-spatiality in an Australian suburb. City \& Society, 29(1), 82-103.

Gardaphe, F. L. (2003). Leaving Little Italy: Essaying Italian American culture. New York, NY: SUNY Press.

Gleye, P. H. (2015). City planning versus urban planning: Resolving a profession's bifurcated heritage. Journal of Planning Literature, 30(1), 3-17.

Goetz, E. G., Williams, R. A., \& Damiano, A. (2020). Whiteness and urban planning. Journal of the American Planning Association, 86(2), 142-156.

Grewal, T. (2020). Inclusive city building: Public engagement processes in the GTA (Working Paper No. 2020/3). Ryerson: Ryerson Centre for Immigration and Settlement and The CERC in Migration and Integration.

Hackworth, J., \& Stein, L. (2012). The collision of faith and economic development in Toronto's inner suburban industrial districts. Urban Affairs Review, 48, 35-61.

Harrison, P., Moyo, K., \& Yang, Y. (2012). Strategy and tactics: Chinese immigrants and diasporic spaces in Johannesburg, South Africa. Journal of Southern African Studies, 38(4), 899-925.

Harwood, S. A. (2005). Struggling to embrace difference in land-use decision making in multicultural communities. Planning Practice \& Research, 20(4), 355-371.

Hulchanski, D. (2010). The three cities within Toronto: Income polarization among Toronto's neighbourhoods, 1970-2005. Toronto: University of Toronto.

Johnson, M. (2017). Revitalizing the suburbs: Immigrants in Greater Boston since the 1980s. In D. Vitiello, \& T. J. Sugrue (Eds.), Immigration and metropolitan revitalization in the United States (pp. 67-79). Pennsylvania, PA: University of Pennsylvania Press.

Keil, R. (2017). Suburban planet: Making the world urban from the outside in. Cambridge: Polity.

Klinenberg, E. (2018). Palaces for the people: How social infrastructure can help fight inequality, polarization, and the decline of civic life. New York, NY: Crown.

Lai, D. C. (1988). Chinatowns: Towns within cities in Canada. Vancouver: University of British Columbia Press.

Li, W. (1998). Anatomy of a new ethnic settlement: The Chinese ethnoburb in Los Angeles. Urban Studies, 35(3), 479-501.

Li, W. (2009). Ethnoburb: The new ethnic community in Urban America. Honolulu, HI: University of Hawaii Press.
Linovski, O. (2012). Beyond aesthetics: Assessing the value of strip mall retail in Toronto. Journal of Urban Design, 17(1), 81-99.

Lo, L., Preston, V. A., Basu, R., Anisef, P., \& Wang, S. (2015). Social infrastructure and vulnerability in the suburbs. Toronto: University of Toronto Press.

Logan, J. (2014). Separate and unequal in suburbia. Providence, RI: Brown University. Retrieved from https://s4.ad.brown.edu/Projects/Diversity/Data/ Report/report12012014.pdf

Logan, J., Zhang, W., \& Alba, R. (2002). Immigrant enclaves and ethnic communities in New York and Los Angeles. American Sociological Review, 67(2), 299-322.

Lung-Amam, W. (2015). Malls of meaning: Building Asian America in Silicon Valley suburbia. Journal of American Ethnic History, 34(2), 18-53.

Nejad, S., \& Walker, R. (2018). Contemporary urban Indigenous placemaking in Canada. In K. Greenop, E. Grant, D. J. Glenn, \& A. L. Refiti (Eds.), The handbook of contemporary Indigenous architecture (pp. 223-251). Singapore: Springer.

Nicholls, W. J., \& Uitermark, J. (2016). Migrant cities: Place, power, and voice in the era of super diversity. Journal of Ethnic and Migration Studies, 42(6), 877-892.

Oldenburg, R. (1999). The great good place: Cafes, coffee shops, bookstores, bars, hair salons and other hangouts at the heart of a community. Cambridge, MA: Da Capo Press.

Pitter, J. (2016). Introduction. In J. Pitter \& J. Lorinc (Eds.), Subdivided: City-building in an age of hyper-diversity (pp. 5-12). Toronto: Coach House Books.

Poppe, W., \& Young, D. (2015). The politics of place: Place-making versus densification in Toronto's tower neighbourhoods. International Journal of Urban and Regional Research, 39(3), 613-621.

Pottie-Sherman, Y., \& Hiebert, D. (2015). Authenticity with a bang: Exploring suburban culture and migration through the new phenomenon of the Richmond night market. Urban Studies, 52, 538-554.

Qadeer, M., Agrawal, S. K., \& Lovell, A. (2010). Evolution of ethnic enclaves in the Toronto Metropolitan Area, 2001-2006. International Migration and Integration, 11, 315-339.

Regional Municipality of York. (2015). Retail trends study. Regional Municipality of York. Retrieved from https://www.york.ca/wps/wcm/connect/yorkpublic/ 88207d21-e1a0-40b4-b0f1-37685e4f2526/Retail_ Trends_Study_Feb_2015_Executive_Summary_ Only.pdf?MOD=AJPERES

Rios, M., \& Watkins, J. (2015). Beyond 'place': Translocal placemaking of the Hmong diaspora. Journal of Planning Education and Research, 35(2), 209-219.

Sandercock, L. (2003). Cosmopolis II: Mongrel cities of the 21st century. London and New York, NY: Continuum.

Schmiz, A., \& Kitzmann, R. (2017). Negotiating an Asi- 
atown in Berlin: Ethnic diversity in urban planning. Cities, 70, 1-10.

Singer, A., Suro, R., \& Wilson, J. H. (2011). Immigration and poverty in America's suburbs. The Brookings Institute. Retrieved from https://www.brookings. edu/research/immigration-and-poverty-in-americassuburbs

Statistics Canada. (2019). Census profile, 2016 census. Statistics Canada. Retrieved from https:// www12.statcan.gc.ca/census-recensement/2016/ dp-pd/prof/details/page.cfm?Lang=E\&Geo1=PR \&Code1=01\&Geo2=PR\&Code2=01\&Data=Count $\&$ SearchText=Canada\&SearchType=Begins \&SearchPR=01\&B1=Visible\%20minority \&TABID =1

Tasan-Kok, T., \& Ozogul, S. (2017). DIVERCITIES, living with urban diversity: The case of Toronto. Amsterdam and Delft: University of Amsterdam and TU Delft.

Thomas, E., Pate, S., \& Ranson, A. (2015). The crosstown initiative: Art, community, and placemaking in Memphis. American Journal of Community Psychology, 55, 74-88.

Toolis, E. E. (2017). Theorizing critical placemaking as a tool for reclaiming public space. American Journal of Community Psychology, 59, 184-199.

Town of Richmond Hill. (2020). Richmond Hill official plan. Richmond Hill: Town of Richmond Hill. Retrieved from https://www.richmondhill.ca/en/sharedcontent/resources/documents/OMB-partiallyapproved-Official-Plan-Part-I.pdf

Tzaninis, Y. (2020). Cosmopolitanism beyond the city: Discourses and experiences of young migrants in postsuburban Netherlands. Urban Geography, 41(1), 143-161.

Vézina, M., \& Houle, R. (2017). Settlement patterns and social integration of the population with an immigrant background in the Montréal, Toronto and Vancouver metropolitan areas: Ethnicity, language and immigration thematic series. Statistics Canada. Retrieved from https://www150.statcan.gc. ca/n1/pub/89-657-x/89-657-x2016002-eng.htm
Viswanathan, L. (2009). 'Postcolonial planning' and ethno-racial diversity in Toronto: Locating equity in a contemporary planning context. Canadian Journal of Urban Research, 18(1), 162-182.

Walton-Roberts, M. (2011). Immigration, the university and the welcoming second tier city. Journal of International Migration and Integration, 12(4), 453-473.

Wang, S., \& Zhong, J. (2013). Delineating ethnoburbs in metropolitan Toronto (Working Paper No. 100). Toronto: Joint Centre of Excellence for Research on Immigration and Settlement.

Watson, S., \& Saha, A. (2013). Suburban drifts: Mundane multiculturalism in outer London. Ethnic and Racial Studies, 36(12), 2016-2034.

Wilson, J. H., \& Svajlenka, N. P. (2014). Immigrants continue to disperse, with fastest growth in the suburbs. Washington, DC: The Brookings Institute.

Zhuang, Z. C. (2015). Construction and reconstruction of ethnicity in retail landscapes: Case studies in the Toronto area. Journal of Urban Design, 20(5), 677-697.

Zhuang, Z. C. (2019). Ethnic entrepreneurship and placemaking practices in Toronto's ethnic retail neighbourhoods. Tijdschrift voor economische en sociale geografie, 110(5), 520-537.

Zhuang, Z. C. (2020). The impact of immigrant entrepreneurship on city building: Learning from Toronto. In C. Y. Liu (Ed.), Immigrant entrepreneurship in cities: Global perspectives (pp. 195-211). Cham: Springer.

Zhuang, Z. C., Hernandez, T., \& Wang, S. (2015). Ethnic retailing. In $\mathrm{H}$. Bauder \& J. Shields (Eds.), Immigrant experiences in North America (pp. 223-247). Toronto: Canadian Scholars' Press.

Zhuang, Z. C., \& Chen, A. X. (2017). The role of ethnic retailing in retrofitting suburbia: Case studies from Toronto, Canada. Journal of Urbanism: International Research on Placemaking and Urban Sustainability, 10(3), 275-295.

\section{About the Author}

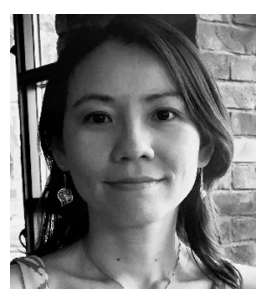

Zhixi Cecilia Zhuang is a Registered Professional Planner and an Associate Professor at Ryerson University's School of Urban and Regional Planning. Her research focuses on ethnocultural diversity, migration and cities, and ethnic entrepreneurship and placemaking. Specifically, she explores the lived experiences of immigrant and racialized communities and their strategies for cultural recognition and social and economic integration. Her research addresses the impacts of global migration on municipal policy and governance, and sheds light on equity-based approaches to planning with diversity. 